\title{
Distribution and Possible Impacts of Toxic Organic Pollutants on Coral Reef Ecosystems around Okinawa Island, Japan ${ }^{1}$
}

\author{
S. T. Imo, ${ }^{2,4}$ M. A. Sheikh,${ }^{2}$ K. Sawano, ${ }^{2}$ H. Fujimura, ${ }^{2}$ and T. Oomori ${ }^{3}$
}

\begin{abstract}
Organic pollutants have detrimental effects on the environment. In this study we evaluated the current status of contamination with organochlorine pesticides (OCPs), organo-tin compounds (OTCs), and polychlorinated biphenyls (PCBs) in the waters in and around Okinawa Island, Japan. Possible toxicological effects of these pollutants on marine life including corals are also discussed. Concentrations of total OCPs in river water were in the range of 1.02-56.4 ng liter ${ }^{-1}$. Among the OCPs, $\alpha-\mathrm{BHC}, \beta-\mathrm{BHC}$, and aldrin were common in river water. OTCs detected in 30 samples of seawater were (mean \pm SD) monobutyl tin $(\mathrm{MBT}), 0.44 \pm 0.75 \mathrm{ng}(\mathrm{Sn})$ liter $^{-1}$; dibutyl tin (DBT), $1.32 \pm 2.70 \mathrm{ng}(\mathrm{Sn})$ liter $^{-1}$; tributyl tin (TBT), $0.72 \pm 2.90 \mathrm{ng}$ (Sn) liter ${ }^{-1}$; monophenyl tin (MPhT), $0.04 \pm 0.42 \mathrm{ng}(\mathrm{Sn})$ liter $^{-1}$; diphenyl tin (DPhT), $0.007 \mathrm{ng}(\mathrm{Sn})$ liter $^{-1}$; and triphenyl tin (TPhT), $0.013 \mathrm{ng}(\mathrm{Sn}) \mathrm{liter}^{-1}$. Highest concentrations of TBT, $28.5 \mathrm{ng}(\mathrm{Sn}) \operatorname{liter}^{-1}$ for water and $172 \mathrm{ng}(\mathrm{Sn})$ $\mathrm{g}^{-1}$ dry weight for sediment, were detected in samples from Itoman Port. Concentrations of total PCBs were $0.05-0.28 \mathrm{ng} \mathrm{liter}^{-1}$ in open ocean and from 1.59 to $2.48 \mathrm{ng} \mathrm{liter}{ }^{-1}$ in coastal waters. Overall, this study shows that the coral reef ecosystems and their adjacent environments around Okinawa Island are contaminated by toxic organic contaminants (OCPs, OTCs, and PCBs). Levels of these contaminants detected in some sites have exceeded the Environmental Quality Target (EQT), which may pose a risk to health of marine life.
\end{abstract}

Organic pollutants have become ubiquitous in the environment, and they represent a global contamination concern. These pollutants include organochlorine pesticides (OCPs), organo-tin compounds (OTCs), and

${ }^{1}$ This study was funded by a grant from the Ministry of Education, Culture, Sports, Science, and Technology of Japan and the 21st Century Center of Excellence (COE) Program of the University of the Ryukyus, Japan. Manuscript accepted 17 August 2007.

${ }^{2}$ Marine and Environmental Sciences, Graduate School of Engineering and Science, Faculty of Science, University of the Ryukyus, Senbaru 1, Nishihara-cho, Okinawa 903-0213, Japan.

${ }^{3}$ Department of Chemistry, Biology, and Marine Science, Faculty of Science, University of the Ryukyus, Senbaru 1, Nishihara-cho, Okinawa 903-0213, Japan.

${ }^{4}$ Corresponding author: (phone: +81-(0) 90-57428098; fax: +81-(0) 98-895-8565; e-mail: taema.imo@ gmail.com).

Pacific Science (2008), vol. 62, no. 3:317-326

(C) 2008 by University of Hawai'i Press

All rights reserved polychlorinated biphenyls (PCBs). Most of these pollutants are released to the environment from anthropogenic sources associated with agricultural activities or residential developments (Fabricius 2005). They reached the aquatic environment through direct runoff, leaching, atmospherically, or through harbors and ports. Some of them are both persistent and toxic, and are widespread in global environments (Fabricius 2005). Studies reveal that emission sources of a number of persistent organic pollutants (such as dichloro-diphenyl-trichloroethane [DDT] and hexachlorobenzene [HCB]) have shifted in the last $20 \mathrm{yr}$ from the industrialized countries of the Northern Hemisphere to less-developed countries in tropical and subtropical regions (Iwata et al. 1994, Tanabe et al. 1994, Fabricius 2005). The annual use of persistent organic pollutants has increased globally more than sixfold since 1960 (Fabricius 2005, Markey et al. 2007), and coastal urbanization is expanding disproportionally to human population growth (Fabricius 2005). 
Around the world, water quality in coastal areas is deteriorating due to rapidly increasing chemical use and land clearing (Iwata et al. 1993, Zhou et al. 2001, Maskaoui et al. 2005, Dimou et al. 2006).

Coral reefs are among the most biologically diverse habitats on earth. They are of ecological importance as substantial sources of seafood, nursery grounds for many fish, and a reservoir of biochemicals for use as medicines (Bryant et al. 1998). Coral reefs are also of economic importance as tourist attractions.

Coral reef ecosystems are exposed to growing loads of pollutants discharged from land. Terrestrial runoff of red clay soils is the major threat to reefs of the Ryukyus Islands, Japan. Excessive sediment is generated from poor land development and agriculture, road building, and forestry (Dai et al. 2002). Already, reefs of Okinawa have been changed from coral reefs to turf algal reefs by damage from sedimentation, crown-of-thorns starfish, and overfishing of the predator sea urchins (Dai et al. 2002). The effects of red soils on coral reef ecosystems have been well documented for the Ryukyu Islands (Kombo et al. 2006). However, information concerning the prevalence and ecotoxicological effects of organic pollutants (OCPs, OTCs, and PCBs) in the coral reef ecosystems is scarce. In this paper we provide information on the spatial distribution and possible toxicological impacts of organic pollutants (OCPs, OTCs, and PCBs) in coral reef ecosystems and their adjacent environments around Okinawa Island, Japan.

\section{MATERIALS AND METHODS}

\section{Sampling}

The sampling sites for OCPs, OTCs, and PCBs are shown in Figure 1. Samples were collected as follows: OCPs (AugustSeptember 2005), OTCs (June-September 2002), and PCBs (September 2001-January 2002).

\section{Chemical Analysis}

The OCP compounds were extracted from river water by a solid-phase extraction (SPE) technique. Methanol and the surrogate standard (4,4'-dibromophenyl) (5 $\left.\mu \mathrm{g} \mathrm{liter}{ }^{-1}\right)$ were added to all samples to allow better extraction (Golfinopoulos et al. 2003, Imo et al. 2007). A $1 \mathrm{ml}$ volume of internal standard (pentachloronitrobenzene, $10 \mu \mathrm{g} \mathrm{liter}{ }^{-1}$ ) was added to all sample vials before gas chromatography (GC) analysis.

The OTCs were extracted from sediments following Ramaswamy et al. (2000). TPrT (Tripropyl tin chloride) $(100 \mu \mathrm{l}$ of $50 \mu \mathrm{g}$ liter $^{-1}$ ) was added to $0.5 \mathrm{~g}$ of freeze-dried sediment as an internal standard. For seawater samples, $5 \mathrm{ml}$ of $1 \mathrm{M}$ acetate buffer was added to 1 liter of filtered seawater, and the $\mathrm{pH}$ was adjusted to 5 . Then $100 \mu \mathrm{l}$ of $50 \mathrm{ng}$ (Sn) liter $^{-1}$ of TPrT was added as an internal standard. The derivatization of OTCs was performed by $1 \mathrm{ml}$ of $5 \% \mathrm{NaBEt}_{4}$, and then $30 \mathrm{ml}$ of hexane was added for liquid/liquid extraction. Finally, the hexane extract was evaporated to $100 \mu \mathrm{l}$ using a stream of nitrogen gas, and $1 \mu \mathrm{l}$ was injected automatically into the gas chromatography flame photometric detector (GC-FPD) instrument for analysis of OTCs.

PCBs in the seawater were analyzed using the method of Iwata et al. (1993). Briefly, 590 liters of seawater was passed through a precleaned XAD-2 column at the flow rate of about $300 \mathrm{ml} \mathrm{min}{ }^{-1}$. PCBs were eluted from the XAD-2 column by using $300 \mathrm{ml}$ of ethanol and then transferred to $100 \mathrm{ml}$ of hexane. The extract was concentrated to 10 $\mathrm{ml}$ in a rotary evaporator under vacuum. Concentrated sulfuric acid and activated florisil columns were employed to clean up the sample extract. A volume of $10 \mathrm{ml}$ of hexane was used to elute all PCBs from the florisil column (Fuoco et al. 1996). The extract was washed by hexane-washed water to remove the residual acid and any polar materials that did not fully partition. Then the sample extract was dried by anhydrous sodium sulfate. Finally, the extract was concentrated down to $100 \mu \mathrm{l}$ using a stream of pure nitrogen gas.

\section{Sample Analysis}

The OCP and PCB residues were analyzed with a gas chromatograph (Hewlett-Packard 6890 Plus), with a micro-cell electron cap- 


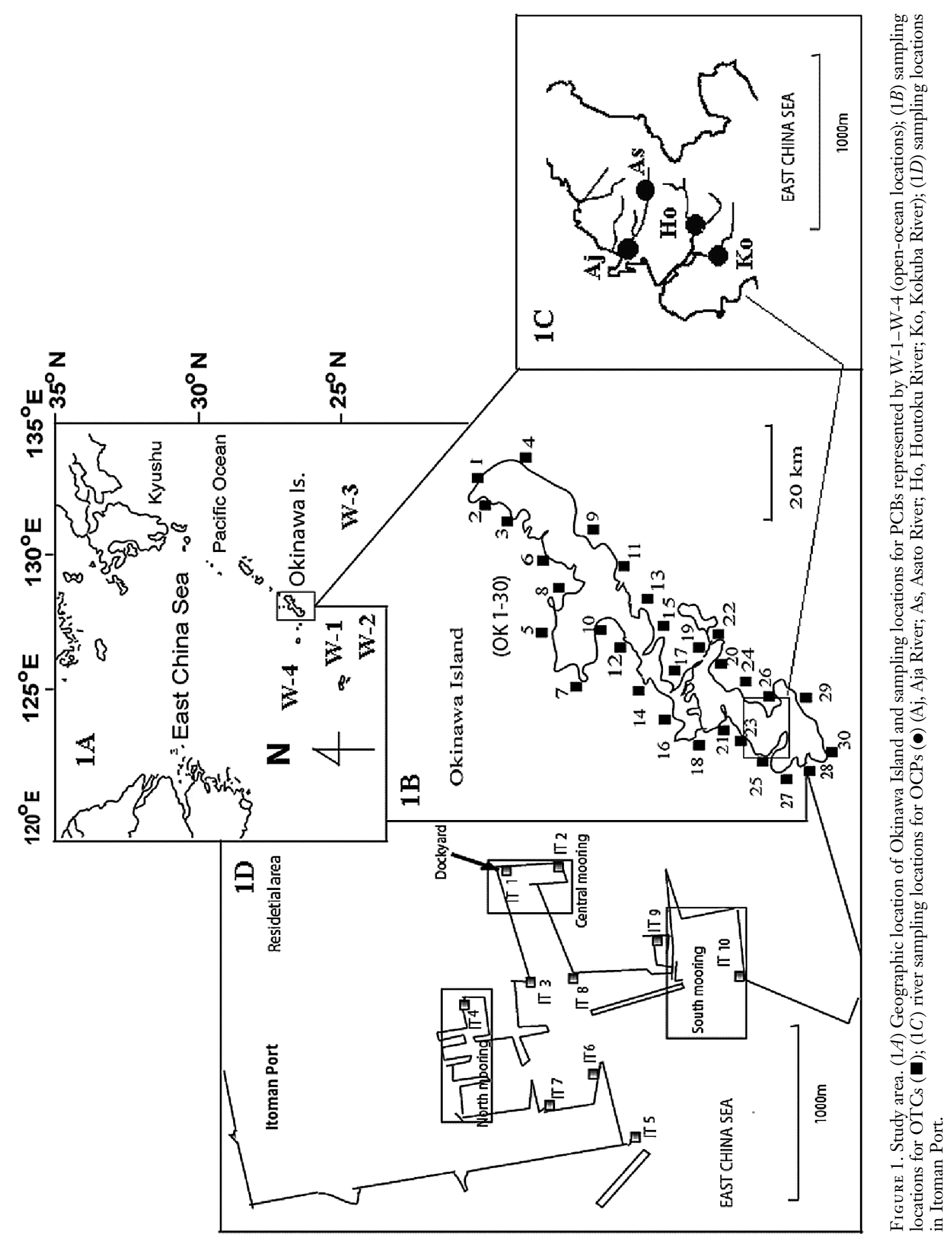


TABLE 1

Levels $\left(\right.$ ng liter ${ }^{-1}$ ) of OCPs (mean \pm SD) in Rivers in Okinawa

\begin{tabular}{|c|c|c|c|c|}
\hline OCPs & Aja & Asato & Houtoku & Kokuba \\
\hline Aldrin & $13.60 \pm 19.2$ & $15.3 \pm 22.9$ & $0.48 \pm 1.4$ & $7.93 \pm 14.6$ \\
\hline Dieldrin & - & $0.21 \pm 0.9$ & - & 二 \\
\hline$\alpha-\mathrm{BHC}$ & $10.20 \pm 16.7$ & $9.83 \pm 18.5$ & $1.60 \pm 5.3$ & $4.72 \pm 8.8$ \\
\hline$\beta$-BHC & $0.30 \pm 0.9$ & - & - & - \\
\hline$\gamma$-BHC & - & - & - & - \\
\hline$\delta$-BHC & - & - & - & - \\
\hline
\end{tabular}

ture detector ( $\mu$-ECD), an autosampler, and ChemStation software. A fused silica capillary column (HP 1) (30 m by $0.32 \mathrm{~mm}$ i.d., 0.25 $\mu \mathrm{m}$ film thickness) was used for the chromatographic separation of pesticides. The OCP compounds were confirmed using a gas chromatography mass spectrometer (GC-MS QP-2010 model). For OTCs, we used a gas chromatograph (Hewlett Packard HP 6890 USA) equipped with an HP-1 methyl siloxane column (30 $\mathrm{m}$ by $0.32 \mathrm{~mm}$ i.d., $0.25 \mu \mathrm{m}$ film thickness) and Flame Photometric Detector (FPD) fitted with a $610 \mathrm{~nm}$ optical filter. The retention times of butyl tin and phenyl tin were determined by comparing the standard and samples, and confirmed by gas chromatography-inductively coupled-mass spectrometry (GC-ICP-MS). Results are presented as mean $\pm \mathrm{SD}$.

\section{Quality Control}

For OCPs, quality control included analysis of water blanks (Milli Q), preextracted and spiked river water $\left(10 \mu \mathrm{g}\right.$ liter $\left.^{-1}\right)(n=8)$. Duplicate analysis of samples from each sampling site showed recoveries of $78 \pm 20 \%$ for aldrin, $75 \pm 11.1 \%$ for $\alpha$-BHC, $85 \pm 12.8 \%$ for $\beta$-BHC, $82 \pm 10 \%$ for $\gamma$-BHC, $80 \pm$ $15 \%$ for $\delta$-BHC, and $84 \pm 12.6 \%$ for dieldrin. The method for measuring butyl tin compounds in sediments was validated by analyzing Certified Reference Material (CRM 7301-a obtained from the National Meteorological Institute of Japan) for butyl tins in marine sediments; the recoveries were $74 \%$ for tributyl tin (TBT) and 106\% for dibutyl tin (DBT). For PCBs, the spiking experiments for water were performed in a 12 liter glass tank using Milli Q grade water and the recovery was $84 \pm 7 \%(n=3)$.

SPSS (Statistical Package for the Social Sciences) software was used for statistical analysis of the data.

\section{RESULTS}

\section{OCPs}

The mean level of each OCP from different rivers is shown in Table 1 . In the Aja River, the highest concentration of an OCP was $55.2 \mathrm{ng}$ liter $^{-1}$ aldrin in September, followed by $35.6 \mathrm{ng}$ liter $^{-1} \alpha$-BHC in August. The mean concentration of OCP was $20.5 \pm 18.2$ $\mathrm{ng}$ liter ${ }^{-1}$ in August and $32.8 \pm 14.9 \mathrm{ng}$ liter $^{-1}$ in September. In the Asato River, the highest concentration of an OCP was $57.3 \mathrm{ng}$ liter $^{-1}$ $\alpha$-BHC in August, followed by $57 \mathrm{ng}$ liter $^{-1}$ aldrin in September. The mean concentration of OCP was $33.4 \pm 19.0 \mathrm{ng}$ liter $^{-1}$ in August and $44.2 \pm 14.1 \mathrm{ng}$ liter $^{-1}$ in September. For the Houtoku River, the highest concentration of an OCP was $21.3 \mathrm{ng}$ liter $^{-1} \alpha$-BHC in September, followed by $5.32 \mathrm{ng}$ liter $^{-1}$ aldrin in September. The mean concentration of OCP was $2.19 \pm 1.10 \mathrm{ng}$ liter $^{-1}$ in August and $13.3 \pm 11.3 \mathrm{ng}$ liter $^{-1}$ in September. In the Kokuba River, the highest concentration of an OCP was $41.2 \mathrm{ng}$ liter $^{-1} \alpha$-BHC in September, followed by $32.1 \mathrm{ng}$ liter $^{-1}$ aldrin in September. The mean concentration of OCP was $20.8 \pm 8.33 \mathrm{ng}$ liter $^{-1}$ in August and $29.8 \pm 8.81 \mathrm{ng} \mathrm{liter}^{-1}$ in September.

OTCs

HORIZONTAL Distribution OF OTCs in Coastal seawater. Butyl tin com- 
TABLE 2

Levels (ng liter ${ }^{-1}$ ) of OTCs in Coastal Okinawa Seawater

\begin{tabular}{|c|c|c|c|c|c|c|c|c|}
\hline Site & MBT & DBT & TBT & $\Sigma \mathrm{BT}$ & MPhT & $\mathrm{DPhT}$ & TPhT & $\Sigma \mathrm{PhT}$ \\
\hline OK1 & $-^{a}$ & - & - & - & - & - & - & \\
\hline OK2 & - & 0.14 & - & 0.14 & - & - & - & - \\
\hline OK3 & 0.37 & 2.10 & 2.24 & 4.71 & - & - & - & - \\
\hline OK4 & - & - & - & - & - & - & - & - \\
\hline OK5 & - & - & - & - & - & - & - & - \\
\hline OK6 & - & - & - & - & - & - & - & - \\
\hline OK7 & 1.54 & 5.98 & 3.13 & 10.65 & - & - & - & - \\
\hline OK8 & - & 0.32 & - & 0.32 & - & - & - & - \\
\hline OK9 & 0.38 & 2.15 & 1.05 & 3.58 & - & - & - & - \\
\hline OK10 & 0.64 & 2.09 & 0.42 & 3.15 & - & - & - & - \\
\hline OK11 & - & 0.34 & - & 0.34 & - & - & - & - \\
\hline OK12 & - & 0.42 & - & 0.42 & - & - & - & - \\
\hline OK13 & 0.37 & 1.56 & 1.06 & 2.99 & - & - & - & - \\
\hline OK14 & - & 0.70 & - & 0.70 & - & - & - & - \\
\hline OK15 & - & 0.08 & - & 0.08 & - & - & - & - \\
\hline OK16 & - & - & - & - & - & - & - & - \\
\hline OK17 & 0.32 & 1.08 & - & 1.40 & - & - & - & - \\
\hline OK18 & 0.50 & 0.65 & 0.27 & 1.42 & - & - & - & - \\
\hline OK19 & 0.64 & 1.73 & 1.02 & 3.39 & - & - & - & - \\
\hline OK20 & 0.13 & 0.40 & - & 0.53 & - & - & - & - \\
\hline OK21 & 0.30 & 1.19 & - & 1.49 & 0.93 & - & - & 0.93 \\
\hline OK22 & 0.45 & 1.04 & 0.28 & 1.77 & - & - & - & - \\
\hline OK23 & 0.65 & 0.91 & 0.11 & 1.67 & - & - & - & - \\
\hline OK24 & 0.82 & 1.68 & 0.89 & 3.39 & - & - & - & - \\
\hline OK25 & 0.51 & 0.86 & 0.39 & 1.76 & - & - & - & - \\
\hline OK26 & 0.47 & 0.45 & - & 0.92 & - & - & - & - \\
\hline OK27 & 0.42 & 0.57 & - & 0.99 & - & - & - & - \\
\hline OK28 & 3.55 & 13.00 & 10.70 & 27.25 & 0.33 & 0.23 & 0.40 & 0.96 \\
\hline OK29 & 0.79 & - & - & 0.79 & - & - & - & - \\
\hline OK30 & 0.47 & 0.15 & - & 0.62 & - & - & - & - \\
\hline
\end{tabular}

${ }^{a}$ Below detection limit.

pounds were detected in 25 seawater samples, and phenyl tin compounds were detected in 2 out of 30 samples collected along the coast of Okinawa Island, as shown in Table 2. The values detected in seawater samples (mean \pm SD) (ng liter ${ }^{-1}$ ) were as follows: MBT $(0.44 \pm 0.75), \quad$ DBT $(1.32 \pm 2.70)$, TBT $(0.72 \pm 2.90)$, MPhT $(0.04 \pm 0.42)$, DPhT (0.007), and TPhT (0.013). Dibutyl tin was a major OTC species detected in coastal waters. It composed about $56.5 \%$ of all OTCs, followed by $30.8 \%$ TBT. The least abundant was MBT, at about $19 \%$ of the total butyl tin species.

HORIZONTAL DISTRIBUTION OF OTCS AT PORT itoman. Seawater: Butyl tin compounds were detected in all samples from Port Itoman (Figure 1D), and phenyl tin compounds were detected in 5 out of 10 sam- ples. The mean levels were $1.35 \pm 1.5 \mathrm{ng}$ (Sn) liter $^{-1}$ MBT, $8.17 \pm 10.7 \mathrm{ng}$ (Sn) liter ${ }^{-1}$ DBT, $6.78 \pm 8.6 \mathrm{ng}$ (Sn) liter ${ }^{-1}$ TBT, and $1.35 \pm 0.2 \mathrm{ng}(\mathrm{Sn}) \operatorname{liter}^{-1} \mathrm{TPhT}$. The highest concentration of TBT, $28.5 \mathrm{ng}(\mathrm{Sn})$ liter $^{-1}$, was detected at site IT1 (wet dockyard). MPhT and DPhT compounds were not detected in any sample. TBT was frequently detected at sites IT2 (middle mooring), IT3 (center of the port), and IT9 (south mooring). DBT was the major species at all remaining sites, and MBT was a minor species around the entire port.

Sediments: Butyl tin and phenyl tin compounds were detected in most samples of sediment collected from Port Itoman. Concentrations of butyl tin ranged between 3.32 $\mathrm{ng}(\mathrm{Sn}) \mathrm{g}^{-1}$ (dry weight) and 13,122 $\mathrm{ng}(\mathrm{Sn})$ $\mathrm{g}^{-1}$ (dry weight) $(1,382 \pm 4,126)$, and concen- 
trations of phenyl tin ranged between 4.40 $\mathrm{ng}(\mathrm{Sn}) \mathrm{g}^{-1}$ (dry weight) and 8,243 $\mathrm{ng}(\mathrm{Sn})$ $\mathrm{g}^{-1}$ (dry weight) $(1,036 \pm 2,538)$. The maximum concentrations of tri-substituted tin were found at site IT1 (wet dockyard) at $172 \mathrm{ng}(\mathrm{Sn}) \mathrm{g}^{-1}$ (dry weight) TBT and 114 ng (Sn) $\mathrm{g}^{-1}$ (dry weight) TPhT. The levels of trisubstituted OTCs in sediments showed strong significant correlation to the levels detected in seawater.

The mean concentrations of OTCs, in ng (Sn) $\mathrm{g}^{-1}$ (dry weight), were $46.4 \pm 60.6$ for TBT; $1,146 \pm 3,170$ for DBT; $349 \pm 926$ for MBT; $13.3 \pm 50.1$ for TPhT; $16.9 \pm 43.6$ for DPhT; and $1,122 \pm 2,459$ for MPhT. The highest concentrations, of $172 \mathrm{ng}(\mathrm{Sn})$ $\mathrm{g}^{-1}$ (dry weight) for TBT and $139 \mathrm{ng}$ (Sn) $\mathrm{g}^{-1}$ (dry weight) for TPhT, were found at site IT1 (wet dockyard), but these species were not detected at site IT10 (outside the port) or site IT7 (center of the port).

The concentrations of OTCs in Port Itoman sediments were correlated significantly with the concentrations of OTCs in seawater $(n=10)$. The statistical relationship of TBT and TPhT was calculated using the following equations:

$$
\begin{gathered}
\text { TBT, } \log y=2.208+0.109 \log x \\
\left(r^{2}=0.59 ; P<.01\right) \\
\text { TPhT, } \log y=0.078+0.0048 \log x \\
\left(r^{2}=0.72 ; P<.01\right)
\end{gathered}
$$

where $x$ is the concentration of OTCs in seawater, in ng (Sn) liter ${ }^{-1}$, and $y$ is the concentration of OTCs in sediments, in $n g(\mathrm{Sn}) \mathrm{g}^{-1}$ (dry weight). For butyl tins, TBT was the predominant species at sites IT5 (port entrance) and IT4 (North mooring), whereas DBT and MBT were predominant at the remaining sites. MPhT was the predominant phenyl tin species in all samples.

\section{PCBs}

PCBs were detected in all open-ocean sampling stations (W-1-W-4) (Figure $1 A)$ in concentrations ranging between 0.053 and $0.28 \mathrm{ng}$ liter $^{-1}$ and in coastal waters (ports) in concentrations of $1.59-2.48 \mathrm{ng} \operatorname{liter}^{-1}$, as shown in Table 3. Total PCBs at $600 \mathrm{~m}$ were relatively higher compared with surface water, but the concentration decreased down

\begin{tabular}{|c|c|c|c|}
\hline Sample Name & Location & $\begin{array}{l}\text { Depth } \\
\text { (m) }\end{array}$ & $\begin{array}{c}\text { Concentration of PCBs } \\
\left(\text { ng liter }{ }^{-1}\right)\end{array}$ \\
\hline \multicolumn{4}{|l|}{ Open ocean } \\
\hline$W-1$ & $26^{\circ} 09^{\prime} \mathrm{N}, 127^{\circ} 35^{\prime} \mathrm{E}$ & 0 & 0.069 \\
\hline$W-1$ & $26^{\circ} 09^{\prime} \mathrm{N}, 127^{\circ} 35^{\prime} \mathrm{E}$ & 55 & 0.15 \\
\hline$W-2$ & $25^{\circ} 50^{\prime} \mathrm{N}, 127^{\circ} 49^{\prime} \mathrm{E}$ & 0 & 0.24 \\
\hline$W-3$ & $26^{\circ} 00^{\prime} \mathrm{N}, 130^{\circ} 57^{\prime} \mathrm{E}$ & 0 & 0.053 \\
\hline W-4 & $26^{\circ} 29^{\prime} \mathrm{N}, 126^{\circ} 59^{\prime} \mathrm{E}$ & 0 & 0.057 \\
\hline$W-4$ & $26^{\circ} 29^{\prime} \mathrm{N}, 126^{\circ} 59^{\prime} \mathrm{E}$ & 600 & 0.28 \\
\hline$W-4$ & $26^{\circ} 29^{\prime} \mathrm{N}, 126^{\circ} 59^{\prime} \mathrm{E}$ & 1,200 & 0.26 \\
\hline \multicolumn{2}{|l|}{ Coastal waters } & Sample & $\Sigma$ PCBs (ng liter ${ }^{-1}$ ) \\
\hline Station & Name & Name & (Dissolved) \\
\hline 1 & Tomari Port & $\mathrm{TP}$ & 2.01 \\
\hline 2 & Naha Port & $\mathrm{NP}$ & 2.48 \\
\hline 3 & Minatogawa & MG & 1.82 \\
\hline 4 & Yonabaru bay & $\mathrm{YN}$ & 1.86 \\
\hline 5 & Chinen village & $\mathrm{CH}$ & 1.59 \\
\hline 6 & Itoman Port & IP & 1.90 \\
\hline
\end{tabular}
to $1,200 \mathrm{~m}$ at $\mathrm{W}-4$. PCBs from surface to

TABLE 3

PCBs in Seawater Collected around Okinawa Island 
deep seawaters are strongly associated with sinking of the particles in the water column.

\section{DISCUSSION}

OCPs

Generally, OCP compounds may be washed into rivers and lakes by rainfall (Golfinopoulos et al. 2003) or by direct discharge. The OCP compounds detected were the isomers of $\operatorname{BHC}(\alpha, \beta)$, aldrin, and dieldrin. The $\alpha-$ $\mathrm{BHC}$, aldrin, and dieldrin were among the OCPs detected in samples from the estuaries of Kokuba River collected in 2005 (Imo et al. 2007). The evidence demonstrates that some of the organic pollutants corresponded to the trajectories arriving at Okinawa directly from localities in Asia such as China and Korea (Primbs 2004). The ranges of OCPs presented here are similar to those found in other regions, such as the coast of Alicante, Spain, where the concentrations of OCPs ranged from 1.3 to $2.3 \mathrm{ng} \operatorname{liter}^{-1}$ (Prats et al. 1992). In the Humber catchments, United Kingdom, the concentrations of OCPs were in the range of 5.78-61.58 $\mathrm{ng} \mathrm{liter}{ }^{-1}$ (Meharg et al. 1998). Concentrations of some OCP compounds are relatively lower in Okinawa than in, for example, Giza, Egypt, where concentrations of OCPs ranged from 20,700 to $86,200 \mathrm{ng} \operatorname{liter}^{-1}$ (El-Kabbany et al. 2000). It is suggested that the low concentrations of some OCPs found in our study may be attributed to the strict regulations governing the use of these compounds in Japan. A previous laboratory study by Markey et al. (2007) demonstrated that OCP (endosulfan) at very low concentrations (0.3-1.0 ng liter ${ }^{-1}$ ) may reduce the settlement and metamorphosis of the coral Acropora millepora by $50-100 \%$ after $18 \mathrm{hr}$ exposure. Although endosulfan was not detected in our study, there is a need of further monitoring and ecotoxicological studies for the future preservation of the coral reef ecosystems around Okinawa Island.

\section{OTCs}

seawater: Concentrations of TBT in seawater ranged from not detectable to $10 \mathrm{ng}$ liter $^{-1}$. The results of this survey revealed that at some sites (OK3, OK7, OK9, OK13, OK19, and OK28 [Figure 1B]) the levels of TBT exceeded the threshold level (1 ng liter $^{-1}$ ) for the most sensitive organisms. The maximum average concentration of TBT in seawater was detected in Port Itoman at $6.78 \pm 8.6 \mathrm{ng}(\mathrm{Sn})$ liter $^{-1}$. Within the port, the highest concentration of TBT, $28.5 \mathrm{ng}$ (Sn) liter ${ }^{-1}$, was observed at IT1. A concentration of TBT of the same order (50 ng liter $^{-1}$ ) coincided with a decrease of zooxanthellae within the tentacles of the sea anemone Aiptasia pallida (Verrill) (Annie et al. 1997, Horiguchi 1998). The mechanism underlying the sensitivity of corals (subclass Cnidaria) to TBT is not known (Watanabe et al. 2006). This shows the need to conduct a broad range of laboratory studies on the effects of TBT compounds on the metabolism (photosynthesis rate, respiration rate and calcification rate) of different species of corals. Our results suggest that the maximum levels of TBT observed in this study may have impacts on corals in or near some ports around Okinawa Island. The concentrations of TBT detected around Okinawa Island were relatively lower than those found in Korean coastal waters, $2.1 \pm 4.8 \mathrm{ng}$ (Sn) liter $^{-1}$ (Shim et al. 2005), and in the English Channel and French Riviera seawater, mean $4.6 \mathrm{ng}$ (Sn) liter ${ }^{-1}$ (Michel and Averty 1999). The spatial distribution of TBT revealed that higher levels were detected around ports compared with other coastal areas. Particularly, TBT has been used as an effective antifouling agent in paints applied to pleasure boats, vessels, large boats, and harbor structures, to name a few. Our results suggest that the TBT detected in seawater coastal areas around Okinawa Island could be due to recent inputs from shipping activity.

SEDIMENTS: TBT contamination in the sediment may seriously affect organisms in the aquatic environment. Negri et al. (2002) reported that sediment containing $8.0 \mathrm{mg} / \mathrm{kg}$ TBT could significantly inhibit larval settlement and metamorphosis of corals. High TBT contents in sediments have been reported in several coastal areas such as Suva harbor, Fiji $(\sim 360 \mathrm{mg} / \mathrm{kg}$ ) (Maata and Koshy 
2001); the western Mediterranean ( $9.2 \mathrm{mg}$ / $\mathrm{kg}$ ) (Tolosa et al. 1992); Portland and Boothbay harbor, USA $(\sim 12.4 \mathrm{mg} / \mathrm{kg}$ ) (Page et al. 1995); Ostuchi Bay, Japan ( 0.64 mg/kg) (Harino et al. 1998); and commercial ports in Okinawa $(\sim 1.8 \mathrm{mg} / \mathrm{kg}$ ) (Wang 2004). Our study revealed that the maximum level of TBT was $\sim 0.17 \mathrm{mg} / \mathrm{kg}$ in station IT1 (Port Itoman). Although this concentration is relatively low, TBT compounds in sediments may possibly pose a threat to marine life, including coral communities around Okinawa Island. Furthermore, the levels of TBT detected at Port Itoman were very high compared with the Environmental Quality Target (EQT) value for TBT in sediments (1-2 ng $\left.\mathrm{g}^{-1}\right)$, which has been implemented in European countries (Ceulemans et al. 1998).

PCBs

Horizontal distributions of PCBs in the open ocean around the Ryukyu Islands were not uniform; the main factor causing this effect might be the proximity of the PCB source. Relatively higher concentrations were found near Okinawa Island (W-1 and W-2) compared with those stations located far from the main island (W-3 and W-4) (Sheikh et al. 2002). The levels of PCBs in this study are relatively lower compared with those in earlier studies. This may reflect the fact that production and use of these compounds has ceased in the world since the 1970s. In the Mediterranean Sea, the concentration of PCBs was in the range of 0.2-8.6 ng liter ${ }^{-1}$ (Elder and Villeneure 1977). In the North Sea and Scottish coast, concentrations of PCBs were in the range of $0.15-0.52 \mathrm{ng}$ liter $^{-1}$ (Dawson and Riley 1977). PCBs have also been implicated in coral reef stress; however there are few conclusive data on ecotoxicological effects of PCBs on coral reefs.

\section{CONCLUSION}

The high levels of organic pollutants (OCPs, OTCs, and PCBs) in the surface water and sediments of some rivers and coastal waters of Okinawa Island are likely to pose a threat to the health of marine organisms such as mollusks and possibly corals. The possible impacts of OCPs on corals include reduced settlement and metamorphosis of corals, and OTCs cause high mortality of aposymbiotic and symbiotic juvenile corals. There are no conclusive data on the ecotoxicological effects of PCBs on corals. Further monitoring of coral reef ecosystems is needed to elucidate the effects of toxic organic pollutants on the subtropical marine life around Okinawa Island.

\section{ACKNOWLEDGMENTS}

We are grateful to colleagues of the analytical chemistry group of the Department of Chemistry, Biology, and Marine Sciences of the University of the Ryukyus for their kind collaboration during this study. We extend our sincere thanks to Dr. Fuke of the Medical School of the University of the Ryukyus for GCMS analysis, Dr. M. Kawano of Ehime University for technical advice on PCB analysis, and Dr. Tao of AIST, Tsukuba, for GCICP-MS analysis of OTCs.

\section{Literature Cited}

Annie, M., P. Emilien, and F. H. Jean. 1997. Effects of butyltins in symbiotic sea anemone Aiptasia pallida (Verrill). J. Exp. Mar. Biol. Ecol. 215:289-304.

Bryant, D., L. Burke, J. W. McManus, and M. Spalding. 1998. Reefs at risk: A mapbased indicator of potential threats to the world's coral reefs. World Resources Institute, Washington, D.C.

Ceulemans, M., S. Slaets, and F. Adams. 1998. Speciation of organotin in environmental sediment samples. Talanta 46:395405.

Dai, C. F., C. Gang, M. Inaba, K. Iwao, F. Iwase, S. Kakuma, K. Kajiwara, T. Kimura, Y. Kotera, Y. Nakano, S. Nojima, K. Nomura, K. Oki, K. Sakai, T. Shinuno, H. Yamano, and M. Yoshida. 2002. Status of coral reefs in East and North Asia: China, Japan, Korea and Taiwan. Pages 153-162 in C. Wilkinson, ed. Status of coral reefs of the world: 2000. Australian Institute of Marine Science, Townsville 
(http://www.aims.gov.au/pages/research/ coral-bleaching/scr2002/pdf/scr2002-08 .pdf [accessed February 2007]).

Dawson, R., and J. P. Riley. 1977. Chlorinecontaining pesticides and polychlorinated biphenyls in British coastal waters. Estuarine Coastal Mar. Sci. 4:55.

Dimou, K. N., S. Tsang-Liang, R. I. Hire, and R. Miskewitz. 2006. Distribution of polychlorinated biphenyls in the Newark Bay estuary. J. Hazard. Mater. 136:103110.

Elder, D. C., and J. O. Villeneure. 1977. Polychlorinated biphenyls in the Mediterranean Sea. Mar. Pollut. Bull. 8:19-21.

El-Kabbany, S., M. M. Rashed, and M. A. Zayed. 2000. Monitoring of the pesticide levels in some water supplies and agricultural land in El-Haram, Giza. J. Hazard. Mater. 1:11-21.

Fabricius, K. E. 2005. Effects of terrestrial runoff on the ecology of corals and coral reefs: Review and synthesis. Mar. Pollut. Bull. 50:125-146.

Fuoco, R., M. Colombini, and C. Ceccarini. 1996. Analytical quality control for determination of polychlorobiphenyles in environmental matrices. Mikrochim. Acta 123:175-183.

Golfinopoulos, S. K., N. D. Anastacia, T. Lekkas, and M. C. Vagi. 2003. Organochlorine pesticides in the surface waters of northern Greece. Chemosphere 50:507576.

Harino, H., M. Fukushima, Y. Yamamoto, S. Kawai, and N. Miyazaki. 1998. Contamination of butyltin and phenyltin compounds in the marine environment of Otsuchi Bay, Japan. Environ. Pollut. 101:209-214.

Horiguchi, T. 1998. Organotin compounds and anomalies of genital organ in sea snail. Kakagu 68:546-551 (in Japanese).

Imo, S. T., M. A. Sheikh, E. Hirosawa, T. Oomori, and F. Tamaki. 2007. Contamination by organochlorine pesticides from rivers. Int. J. Environ. Sci. Technol. 1:1-9.

Iwata, H., S. Tanabe, N. Sakai, A. Nishimura, and R. Tastukawa. 1994. Accumulation patterns of polychlorinated biphenyl congeners and organochlorine pesticides in steller sea eagles and white-tailed sea eagles, threatened species in Hokkaido, Japan. Environ. Pollut. 4:842-847.

Iwata, H., S. Tanabe, N. Sakai, and R. Tatsukawa. 1993. Distribution of persistent organochlorines in the oceanic air and surface seawater and the role of ocean on their global transport and fate. Environ. Sci. Technol. 27:1080-1098.

Kombo, M. M., S. S. Bakari, S. Ryuichi, and T. Akira. 2006. Chemical impacts of the acidic red soil on seawater. Galaxea 8:1323.

Maata, M., and K. Koshy. 2001. A study on tributyltin contamination of marine sediments in the major ports of Fiji. South Pac. J. Nat. Sci. 19:1-4.

Markey, K. L., A. H. Baird, C. Humphrey, and P. A. Negri. 2007. Insecticides and fungicide affect multiple coral life stages. Mar. Ecol. Prog. Ser. 330:127-137.

Maskaoui, K., J. L. Zhou, T. L. Zheng, H. Hong, and Z. Yu. 2005. Organochlorine micropollutants in the Jiulong River estuary and western Xiamen Sea, China. Mar. Pollut. Bull. 51:950-959.

Meharg, P., J. Wright, and D. Osborn. 1998. Polycyclic Aromatic Hydrocarbon (PAH) deposition to vegetation and soil following a large-scale chemical fire. Environ. Pollut. 99:213-220.

Michel, P., and B. Averty. 1999. Distribution and fate of tributyltin in surface and deep waters of the northwestern Mediterranean. Environ. Sci. Technol. 33:25242528.

Negri, A. P., D. S. Luke, S. W. Nicole, and J. H. Andrew. 2002. Understanding shipgrounding impacts on a coral reef: Potential effects of anti-foulant paint contamination on coral recruitment. Mar. Pollut. Bull. 44:111-117.

Page, D. S., C. C. Ozbal, and M. E. Lanphear. 1995. Concentrations of butyltin species in sediments associated with shipyard activity. Environ. Pollut. 91:237-243.

Prats, D., F. Ruiz, and D. Zarzo. 1992. Polychlorinated biphenyls and organochlorine pesticides in marine sediments and sea water along the coast of Alicante, Spain. Mar. Pollut. Bull. 24:441-446. 
Primbs, T. 2004. POPs and other anthropogenic SOCs in Eurasian air masses measured at rural site in Okinawa, Japan. Poster presentation at EPA STAR Graduate Fellowship Conference (http://es.epa .gov/ncer/fellow/posters/ppt/primbs_2004 _star.pdf [accessed July 2005]).

Ramaswamy, B. R., H. Tao, T. Nakazato, and A. Miyazaki. 2000. A quantitative extraction method for the determination of trace amounts of both butyl-, phenyltin compounds by gas chromatographyinductively coupled plasma mass spectrometry. Analyst 125:1757-1763.

Sheikh, M. A., T. Oomori, and Y. Odo. 2002. Polychlorinated biphenyls in sub-tropical marine environment: A case study in seawaters collected around Ryukyu Islands, Japan. Bull. Fac. Sci. Univ. Ryukyus 74:65-72.

Shim, W. J., K. Joong, J. Oh. Ryoung, N. K. Sook, and S. Hyung. 2005. Accumulation of tributyltin in the blood of fish: Its application for monitoring in the marine environment. J. Environ. Toxicol. Chem. 21:1451-1455.

Tanabe, S., H. Iwata, and R. Tatsukawa.
1994. Global contamination of persistent organochlorines and their ecotoxicological impact on marine mammals. Sci. Total Environ. 154:163-177.

Tolosa, I., L. Merlini, N. de Bertnand, J. M. Bayona, and J. Albaiges. 1992. Occurrence and fate of tributyl and triphenyltin compounds in western Mediterranean coastal enclosures. Environ. Toxicol. Chem. $11: 145-155$.

Wang, X. 2004. Distribution and behaviour of organotin compounds in the aquatic environment in Okinawa Island. M.S. thesis, University of the Ryukyus, Okinawa, Japan.

Watanabe, T., I. Yuyama, Y. S. Suzuki, and S. Yasumura. 2006. Toxicological effects of biocides on symbiotic and aposymbiotic juveniles of the hermatypic coral Acropora tenuis. J. Exp. Mar. Biol. Ecol. 339:177188.

Zhou, J. L., K. Maskaoui, W. Y. Qui, H. S. Hong, and Z. D. Wang. 2001. Polychlorinated biphenyls congeners and organochlorine insecticides in the water column and sediments of Daya Bay, China. Environ. Pollut. 113:373-384. 